\title{
The Cultural Dimension of Spanish Universities: The state of the issue
}

\author{
Antonio Javier González Rueda \\ UNIVERSIDAD DE CADIZ \\ antonio.gonzalez/auca.es \\ Antonio Ariño Villarroya \\ UNIVERSITAT DE VALÈNCIA \\ antonio.arino\&uv.es
}

Received: 10/06/2019

Accepted: 27/03/2020

\begin{abstract}
The cultural dimension of Spanish universities has changed markedly, especially since the restoration of democracy in Spain in the late 1970s. This study reflects on the terminology and the historical evolution of Spanish universities, comparing their development within a broader world context. It also analyses the present state of affairs through two complementary pieces of field work. The paper concludes by examining the issues and hurdles that until recently were the third dimension of university life after teaching and research.
\end{abstract}

Keywords: university cultural management, university extension, university missions, sociology of culture, cultural studies.

Corresponding author: Antonio J. González Rueda. Comisionado para el Plan Estratégico de la Universidad de Cádiz. Vicerrectorado de Política Educativa. Centro Cultural Reina Sofía. Sede del Rectorado de la Universidad de Cádiz. Paseo Carlos III, 9. 11.003-Cádiz (Spain).

Suggested citation: González Rueda, A. J. and Ariño Villarroya, A. (2020). The Cultural Dimension of Spanish Universities: The state of the issue. Debats. Journal on Culture, Power and Society, 5, 181-195. D0I: http://doi.org/10.28939/iam.debats-en.2020-10

Culture is a basic need. It contributes to people's well-being insofar as it gives them the tools to embark on the human adventure. It is a factor that provides greater complexity, enriching experience. Since Montaigne, we know that it is what makes us who we are. Yet culture does not guarantee anything be it good, truth, happiness, or success 


\section{THE TERM CULTURAL DIMENSION OF UNIVERSITIES}

Back in 2012, we proposed the term cultural dimension of universities to the academic community, the cultural management community, and society in general. We commended the term as an umbrella one to describe all those tasks that universities engage in when it comes to university culture and other related disciplines (Ariño Villarroya and González Rueda, 2012). Although the term has not taken root in the professional and social circles that universities operate in, it has been echoed in academe (Penelas, 2013) and in the media (Mejía Arango, 2018).

Clearly, the proposed epistemological use of the Cultural Dimension ('CD' hereinafter) is hard to apply to university management or other activity given that we are dealing with a category incorporating diverse realities under a very broad heading (dimension) that is described and specified by the word cultural. It is not a question of proposing a different framework but rather of seeing this dimension of university activity as a paradigm that even-handedly defines both the teaching and research dimensions of such institutions.

In addition, $\mathrm{CD}$ is something that gives consistency to a historical track record extending back almost 150 years, ever since the university extension in Cambridge in 1871 (Palacios Morini, 1908: 126) and running up to recent concerns over Social Responsibility (Ruiz, 2016). Furthermore, it is a term that spans both historical and normative legitimacy in universities' cultural function (Ariño Villarroya, 2007). Culture has been part of the university's functions and missions since the beginning. Nevertheless, it is hard to define and locate this dimension for various reasons:

- University extension was originally thought of as an extra mission at a time when university communities were much smaller than they are today. Now that university communities have grown like Topsy, their members are, as Rowan puts it, both creators and consumers of cultural goods and services (García, 2019).
- Traditionally, the university sphere has created sundry misunderstandings of culture. One of them tends to identify knowledge with culture; another identifies culture with The Arts and The Humanities. If culture is knowledge, universities are thought of as institutions in which all their actors and functions are automatically of a cultural nature. By contrast, if culture is the Arts then only that part of a university's activities are cultural in kind (González Rueda, 2004: 181).

- University extension as a teaching experience had many illustrious promoters, such as Clarín, Aniceto Sela, and Paulo Freire. Yet our pride in this golden past sometimes makes it harder to understand CD's present.

- Unlike in Spain, in the English-speaking world CD's development took place as an experiential complement for students within decentralised faculties or schools. For instance, Harvard currently has an Extension School and a Summer School, which form part of the university's Arts and Sciences Faculty. ${ }^{\mathbf{1}}$

- In The United States and The United Kingdom, thematic clubs form part of the CD and are strongly supported by students.

\section{A BRIEF HISTORICAL REVIEW}

While we are speaking of university extension (historically, one of CD's main planks), we shall now recall its main achievements and bring these up to date.

The historic concept of university extension is almost as old as universities themselves. That is because university teachers tried to foster so called popular education right from the start. For instance, the finan-

1 Harvard University. Web Online and On-Campus Courses | Harvard Extension School. Accessed 6 ${ }^{\text {th }}$ April 2019 from https://www.extension.harvard.edu/academics/onlinecampus-courses. 
cier Thomas Gresham gave lectures to merchants and craftsmen in $16^{\text {th }}$-Century London. William Dills undertook similar initiatives at Cains College, Cambridge in 1630 (Melón Fernández, Álvarez Antuña, Friera Suárez and Ruiz de la Peña, 2002: 130). Nevertheless, it was not until 1871 (against the background of the trouble, politically turbulent $19^{\text {th }}$-Century and the emerging 'social question') that a university extension school was created in Cambridge (Palacios Morini, 1908: 126) on a semi-official footing. Oxford and other universities followed in Cambridge's footsteps. In The United States the University Extension Journal was first published in 1890 (Welch, 1973: 201) and the Philadelphia American Society for Extension of University was founded.

Draper argues that the beginning of the university extension programme at Cambridge (and elsewhere) lay in lectures for women, which were later extended to men by popular request:

In this instructive booklet, the Master of The Temple clearly explains the origins and path of a remarkable movement that has benefited universities and the masses alike. Prof. James Stuart's initiative in Cambridge began when he started giving classes to women in 1867 . He soon realised that men were just as keen to attend his talks on important matters. Oxford followed Cambridge's example in 1878 and since then, London, Manchester and newer universities have followed in his footsteps. (Draper, 1923)

Following Britain's lead, Germany undertook major extension programmes in large industrial centres. In France though, the idea underpinning university extension programmes was hidden by the growth of popular universities that catered to a narrower segment of the population. In Spain, there are some interesting precedents in this field prior to the University of Zaragoza but the official birth of university extension in this country can be dated to the $11^{\text {th }}$ of October 1898 and took places at Oviedo University. In the words of Professor Aniceto Sela (who was a notary at the time):
In a Faculty Meeting held on the $11^{\text {th }}$ of October 1898, Leopoldo Alas spoke of the important points raised in Mr. Altamira's speech inaugurating the academic year. He spoke of the work being done abroad to foster popular culture and proposed to the Faculty that Oviedo University take up this invaluable line of work by beginning its own University Extension. (Coronas, 2005)

Sela recalled that "Our universities need more than any other to go out to the people, educate it, and bend themselves to the great task of actively educating the nation. Such an approach would get swifter results than waiting for pure science alone to yield its fruits". The idealism (not to say a certain naivety) of those backing Spanish universities' extension programmes led their detractors to label the ideas as "sectarian propaganda shot through with Republican anti-clericalism, and a cheap Socialism that was hypocritical, pedantic, and pointless" (Melón Fernández, 1987: 105).

The purpose of this paper is not to set out the historical path taken by CD (a fascinating subject to be sure but that would require deeper research of the source materials) ${ }^{2}$. Yet we can reasonably conclude that the social and teaching movement enshrined by university extension was one of the many fruits of the ideals spread by The French Revolution. University extension and 'popular universities' began by taking the same path but soon there came a parting of the ways given that the former tended to identify more with Reformism whereas the latter broke with the past. Nevertheless, they both tried to address the same dire social problems of the time.

In Latin America, university extension is considered universities' third function or mission, in addition to teaching and research. That is the case now and it was also true in the past. As in the Spanish case, it is more of an approach to teaching than a function - something that sets it apart from the mainstream

2 This work is recommended for the rich detail contained in the chapter on university extension, which Leopoldo Palacios Morini takes up in his work on popular universities (Palacios Morini, 1908). 
European model. The Latin American model is not only applied in universities but also in the Health field and in rural areas. The contributions made by Paulo Freire (appointed Director of Recife University's Cultural Extension Department in 1961) provide a good example of the approach taken. The post gave Freire a golden opportunity to put his teaching theories into practice. Among other achievements, he taught 300 workers from the local sugar cane plantations to read in just 45 days (Freire, 1973). The main planks of Latin American university extension are: knowledge and know-how; professional and technical skills; 'outside-in' learning. Like in Spain, local practice went hand-in-hand with theory. That, in our view, is why it has proven impossible to construct a shared concept of university extension.

During the spread of university extension throughout Europe and Latin America, there has been a belief in the emancipating power of culture and in universities' role in making it felt. These notions are where universities' present concept of their present social role spring from. After its birth and consolidation in the second half of the $20^{\text {th }}$ Century, the movement has taken different paths in different countries. That said, there is a general tendency to standardise and institutionalise $\mathrm{CD}$ activities against the background of ever larger universities (attended by a burgeoning part of the populace).

Focusing on the Spanish case, the scant literature on the subject fostered the idea that university extension had languished during the Franco dictatorship. Although there is an element of truth in this, partial studies by Cantero (2006) have shown that there was more going on during this period that had been thought. Nevertheless, the fact is that CD in Spain began to wax following the passing of Constitutional Law 11/1983, reforming universities. Article 1, Section $2 \mathrm{~d}$ of this Act covered and legitimised CD by creating Vice-Rectors for University Extension, Cultural Extension, and Cultural Activities.

This framework was strengthened in 2007 with the passing of Constitutional Act 4/2007 (LOMLOU), which amended the Constitutional Act for Universities, passed in 2001 (Spain, 2007). The amended Act included sundry new provisions. One covered "the dissemination of knowledge and culture through university extension and lifelong learning (Article 1) as a university function". It also stressed that "universities' missions include imparting the knowledge that the professions need in their respective scientific, technical, and artistic fields and the transmission of culture in general" (Article 33). Last but not least, the amended Act dedicated a complete article covering university culture (Article 93):

Universities have a duty to link students with the ideas of their time. To this end, universities shall find the means needed to boost their commitment to intellectual reflection, and the creation and spreading of culture. Specifically, universities shall seek to narrow the gap between humanistic and scientific cultures, and strive to pass on knowledge of Science to society at large.

Article 46 of LOMLOU refers to "academic recognition of (...) cultural activities (...) and of non-traditional students" (Article 42). When the Act refers to the statutes of each university, the amended Act tends to repeat previously enunciated principles, often word for word, including concepts such as university culture, extension, and cultural activities in various sections of these Statutes but usually framed in terms of 'mission' rather than in regulatory ones. In this respect, $\mathrm{CD}$ is set out in long preambles instead of as practical guidelines.

The need for internal and external recognition led Spanish universities to make various attempts to co-ordinate their efforts and to work in a networked fashion following the enactment of the LRU. In general, they tried to emulate the success of the model in other fields within the framework of Spain's Council of University Rectors (hereinafter CRUE) ${ }^{3}$, but alas to no avail. The following list of these attempts is illustrative rather than exhaustive:

3 Conference of Spanish University Rectors (CRUE) - Sectoral. Accessed $28^{\text {th }}$ March 2019 from http://www.crue.org/ SitePages/Sectoriales.aspx 
- In February 1991, the Vice-Rectors of most public universities met at La Laguna University. This meeting recognised the need to set up professional management teams to ensure Vice-Rectors' Offices had sufficient, stable funding (Solicitud de creación de la comisión sectorial de extensión universitaria en el seno de la CRUE, 2003).

- In 1991 and 1992, an informal co-ordination group for university extension was set up and contacts were begun with CRUE to establish sectoral working group. Contacts were also forged with the Ministry of Culture, and departments with responsibilities in this field in Spain's 'Autonomous Communities' (regions) with a view to working together.

- In 1992 and 1993, sundry plenary sessions of University Extension Vice-Rectors were held (in Córdoba, Alicante, and in The Balearic Islands) which culminated in the Barcelona University Management Workshops, held in November 1993.

- In 1998, two more meetings were held, one in Valencia, the other in Oviedo. The one in Valencia reflected the nature of university culture in the $21^{\text {st }}$ Century. The meeting served as the prelude for the International Iber-American Congress (CII) held in Oviedo to mark university extension's centenary. Oddly enough, no Minutes were kept of this meeting which means we can say little about it (García Guatas, 2004). The need to create a special sector for university extension was raised at both meetings.

- In 2002, The Biar Declaration on University Extension was drawn up in to mark the International Congress on Rafael Altamira, held in Biar, Alicante. The declaration's impact on CRUE was negligible.

- In 2017, the University and Culture: The balance of their relationship (González Rueda, 2017), which was known as The Declaration of Cadiz, proposed the setting up of a working party under CRUE's aegis (Parodi Álvarez, 2017).

In the regional settings, co-ordination proved most successful and long-lasting in the case of the Andalus University Council's Extension Sector, which in 2006 gave rise to Proyecto Atalaya [Watchtower Project], which brought together ten Andalus universities and in which the Watchtower Project Cultural Observatory (fostered by Cadiz University and International University of Andalusia (Red Telescopi) established best practices.

We shall now turn to the international scene. In the English-speaking world, the term university extension continues in widespread use and is familiar to the general public. Proof of this can be found in the fact that the term merits an entry in Encyclopaedia Britannica. In this context, university extension is a division of higher education catering to those who are not full-time students. It thus embraces distance education activities, continued education, and adult education. It is thought to have helped bring women in higher education:

University extension, division of an institution of higher learning that conducts educational activities for persons (usually adults) who are generally not full-time students. These activities are sometimes called extramural studies, continuing education, higher adult education, or university adult education. Since its inception, group instruction in the form of formal lectures, discussion groups, seminars, and workshops has remained the core of extension courses. One important consequence of the extension movement was that it helped to establish higher education for women.

In 1867, a professor at Cambridge University began offering an extension course. In the 1880s, such courses began to bloom in centres throughout England. Then around 1885, university leaders in The United States became aware of the programmes at British universities. The most significant development came at the University of Chicago when extension 
was included as an integral part of the design for the new university, incorporating funding for off-campus centres, correspondence instruction, and various other programmes.

At many American universities the number of adults engaged in extension programmes has become greater than the number of full-time students enrolled on campus, and specialised units offering such programmes have grown rapidly. Some universities reorganised themselves to give extension an important place as an all-institutional function paralleling that of resident teaching and research.

Elsewhere in the world, university extension has gone furthest in English-speaking countries. In some instances, following British practice, the term extramural studies is used.

\section{DIAGNOSIS OF THE CULTURAL DIMENSION TODAY}

So far, we have looked at the CD's history, regulations, and operational aspects, especially with regard to Spain. One of the problems emerging from this review is the lack of focus on internal recognition of the CD. This is a big hurdle when it comes to ranking tables, and national and international awards for university excellence. The main world rankings cover research and knowledge transfer dimensions (in all cases), and teaching and faculty (in some cases) but there is no ranking covering the cultural dimension. Of less importance is the fact that some indicators have weak links to intellectual property and patents. Only the CYD (Knowledge and Development Foundation) ranking includes Artistic Production ${ }^{\mathbf{4}}$ in the research field. The CRUE report Universities in Figures contains a small set of indicators on university culture. Efforts made by Universitat de València (UV) to include the $\mathrm{CD}$ dimension in the U-Ranking BBVA were thwarted. In the case of external acknowledgement and awards, CD's invisibility can be seen in Red Telescopi's review

4 Number of artistic results based on the Creative Arts and the Scenic Arts, split by TRS (ETC). of best practices in this field at Cadiz University. Only two were mentioned: Observatorio Atalaya, and Herramienta Celama (Red Telescopi).

In a complementary fashion, one way of broadly analysing acceptance of the term university cultural dimension is the presence of the word 'culture' in Spanish Vice-Rectors' job titles. During a University Summer Course on culture (2018) ${ }^{\mathbf{5}}$, we looked at the titles given to Vice-Rectors working in this field. To this end, we made an exhaustive search of the institutional web sites of 76 public and private universities linked to the $\mathrm{CRUE}^{6}$ web site. The analytical ${ }^{7}$ approach was based on searching for the Vice-Rectorate in question in each university and extracting the descriptors and counting the repetition of terms. Our findings are set out as a label cloud (see Figure 1).

\section{Figure 1 Label cloud emerging from analysis}

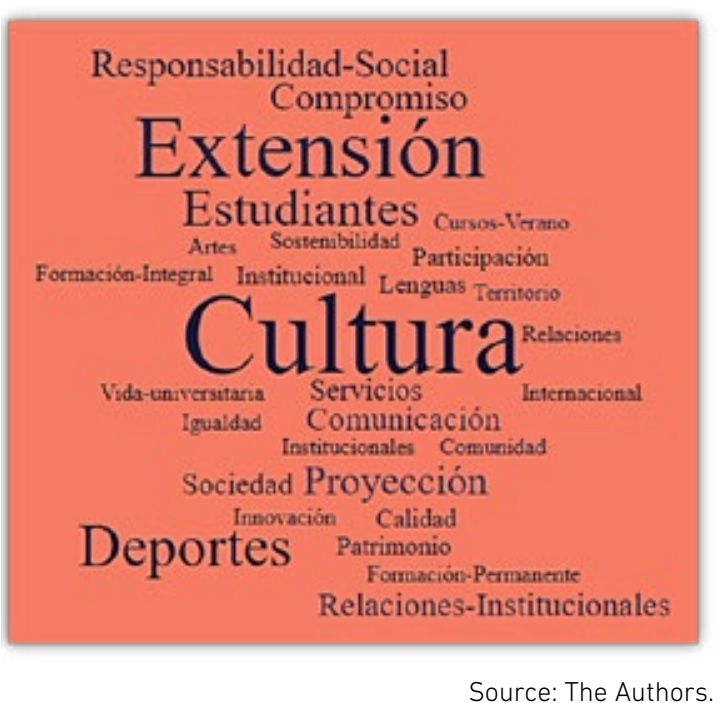

5 Cultura en/desde/para la Universidad. (2018). Accessed $28^{\text {th }}$ March 2019 from https://www.uik.eus/es/culturaendesdepara-la-universidad.

6 Conferencia de Rectores de las Universidades Españolas. Accessed 28 $8^{\text {th }}$ March 2019 from http://www.crue.org/ universidades/SitePages/Universidades.aspx.

7 Analysis carried out by examining institutional web sites on the $4^{\text {th }}$ July 2018. 
As Figure 1 shows, the descriptor that appears most is Culture (26), followed by Extension (19) and Sports (11) [Cultura, Extensión and Deportes in the Spanishlabelled diagram]. A nuance here is that Culture is easily the most used word (whether directly or indirectly), followed by Extension (the latter being historically associated in Spain with university culture and its dissemination).

1. Of the 26 private universities, 20 had no Vice-Rector expressly covering the cultural dimension.

2. Over the years, the cultural dimension increasingly appears in the company of other sub-functions, often tacked on as 'fellow travellers' (Sport, Social Projection, Communication, and Quality).

3. Of the 55 universities including the cultural dimension in their organisation charts, $53 \mathrm{did}$ so through a Vice-Rectorate.

4. The number of universities including the cultural dimension in 'omnibus' vice-rectorates is on the rise. The upshot is that the cultural element is watered down or is just thrown in as an afterthought to the latest fads (students, projection, responsibility, and so forth).

Cultural dimension is a valuable concept for undertaking broad scholarly analysis. Yet it is hard to find a common framework identifying the cultural dimension from an organic or functional standpoint in university organisation charts. In our view, bodies such as a Vice-Rectorate for University Culture or a Vice-Rectorate of Cultural Extension would be the right places to make up these shortcomings at Spanish universities. The former would link universities with less of a track record in the cultural field. Meanwhile, the latter would incorporate the tradition of those universities that have single-mindedly pursued a cultural mission from the early $20^{\text {th }}$ Century onwards. For Ariño, university culture should embody the following traits:
Scientific: A culture of logos to fight prejudice; evidence and argument based on the scientific method.

Critical: A culture based on natural scepticism that questions hegemonic visions legitimising 'the powers that be'.

Creative and innovative: insofar as it fosters new approaches to improving people's quality of living.

Academic: "operating on the synthesis, interrelationship and co-ordination of knowledge in an age of global, trans-border problems" (Ariño Villarroya, 2016).

We proposed a self-diagnosis approach in a 2018 Summer Course (Culture in and from Universities) that we gave at The University of The Basque Country. At the time, we envisaged that such self-diagnosis would need validation by experts - that is to say, academic managers and professionals drawn from Spanish universities' Vice-Rectorates for Culture.

Following on from earlier fieldwork on Vice-Rectorate names, we selected 41 universities (39 public ones, 2 private ones) that had a track record in this field and whose web sites contained e-mails of academic managers and technical staff. Eighty-one invitations were sent to individual e-mail addresses, inviting the recipients to answer a questionnaire created by the LimeSurvey platform at Cadiz University to validate the aforementioned diagnosis of the cultural dimension. Fifty-one fully-completed questionnaires were returned - a $63 \%$ response rate. Of those completing the survey, 69\% were Administrative and Service Staff (hereinafter 'ASS') and 31\% were Teaching and Research Staff (hereinafter 'TRS'). These figures were consistent with the higher proportion of admin and technical staff at universities. From the gender angle, 53\% of respondents were men, and $47 \%$ were women. We shall now see the extent to which the self-diagnosis was supported by examining the following 24 hypotheses on the cultural dimension at universities: 
1. Hypothesis: The university's cultural dimension has vague, poorly-defined goals. A majority of the respondents agreed with the statement (57\%). Maybe one of the reasons for this is that these Vice-Rectorates are given more freedom of action and there is less control over their activities than over the universities' two main missions (teaching and research). From our standpoint, the CD does not have an express, broadly-accepted mission. Unlike in Latin America, in Spain the CD is not incorporated in either teaching or in research to the slightest degree. In Latin America - somewhat confusingly - it "constitutes one of the key functions of universities and is the synthesis of its other functions to achieve social belonging. It thus incorporates both teaching and research" (Cedeño Ferrín, 2012). In this respect, the Latin American concept seems to be fairly close to the Spanish concept of knowledge transfer, albeit with a social and communitarian twist.

2. Hypothesis: The CD incorporates a set of sub-dimensions that makes it hard to establish its mission. A sizeable majority of respondents agreed with the statement (61\%). The CD, as we have noted, incorporates so many sub-dimensions and states that it is virtually impossible to establish the $\mathrm{CD}$ mission: sports, scientific divulgation, university publishing, summer schools, adult education, museums, heritage, and so forth. That is why it is hard to state the mission clearly.

3. Hypothesis: The $\mathrm{CD}$ is peripheral to university governance. A large majority of respondents agreed with the statement $(71 \%)$, especially among administrative staff. The $\mathrm{CD}$ is peripheral to university governance which, as we have noted has both pros (more freedom) and cons (the $\mathrm{CD}$ being dismissed as being of little importance).

4. Hypothesis: The university's $C D$ is led more by collective agents and individu- als than by the Vice-Rectorates (centres, departments, research institutes, colleges, chairs, associations, faculty, and so on). These agents work together rather than compete with the Vice-Rectorates of each university. Once again, $71 \%$ of respondents agreed that the $C D$ was not only pursued in the Vice-Rectorates with a special remit in this field but also by all the collective agents just listed, and collaborating/competing individuals (as the case may be). In other words, these Vice-Rectorates only manage part of an institution's CD.

5. Hypothesis: The staff working in the CD field have improved in both number and qualifications compared with their forebears in the 1990s. On the downside, the aging of today's staff complicates generational renewal. There was no strong feeling one way or the other on this statement (51\% of respondents overall agreed with the statement but more ASS staff concurred). Maybe this was because few respondents knew the situation in the 1980s and 90s when support for the CD was lukewarm.

6. Hypothesis: The university's cultural facilities are better than they were a few years ago but they are highly dependent on funding for their upkeep and activities. An overwhelming majority of respondents (92\%) agreed with the statement. Here, CD units can be thought of as 'giants with feet of clay', especially in the seemingly endless aftermath of the 2009 Financial Crisis.

7. Hypothesis: That Vice-Rectorates for the CD hardly share their programmes and projects with those carried out by other Spanish universities in general and with those of other European universities in particular. An overwhelming majority of respondents (84\%) agreed with the statement, albeit with less support from those occupying academic posts. 
8. Hypothesis: The cultural and creative programmes proposed by CD Vice-Rectorates are intermittent. There was no strong feeling one way or the other on this statement $(51 \%$ of respondents disagreed with the statement). Nevertheless, a future qualitative study on $\mathrm{CD}$ programmes may shed further light on this aspect.

9. Hypothesis: The CD programmes offered show little innovation. A majority of respondents agreed with the statement (57\%), although it received greater support from ASS staff than TRS staff. The two differing visions of the innovative nature (or lack of it) are noteworthy and may be linked to how those occupying a temporary post (TRS) or a permanent one (ASS) see things. It seems that those briefly in the post look at the issue through rose-coloured glasses while those who are longer in the job take a more jaundiced view of the way things are.

10. Hypothesis: There is a lack of academic networks and co-ordination techniques in the CD field. The overwhelming majority of respondents agreed with the statement (90\%), making it clear just what the shortcomings are. If these are overcome, there is a chance of boosting innovation and bringing things up to date.

11. Hypothesis: CD programmes mainly focus on the artistic sphere. A majority of respondents agreed with the statement (59\%). That said, only a slender majority of TRS staff agreed with the statement. The emergence of Scientific Culture and Innovation Units [UCC+i is the Spanish acronym] seems to confirm this diagnosis, given that CD Vice-Rectorates and units are no longer seen as the best way of incorporating science and technology in their programmes.
12. Hypothesis: $\mathbf{C D}$ activities are either far removed from or are not linked to students' cultural skills. A sizeable majority of respondents agreed with the statement (67\%) This points to a situation that needs remedying but present syllabuses, the nature of the student body, and their timetables will make this hard. That said, while there is clearly a gap between the $\mathrm{CD}$ and universities, to varying degrees the same gap appears in associations, sports, social activities, and even in complementary academic and research activities.

13. Hypothesis: CD Vice-Rectorates have adapted fairly well (and maybe even better than other university dimensions) to the ever-changing nature of the world around us (social networks, video platforms, cultural content ' 3.0 ', etc.). A sizeable majority of respondents agreed with the statement $(63 \%)$, revealing that one of the strengths of $\mathrm{CD}$ is that it focuses more on communication through social networks than on generating digital cultural content, and media labs.

14. Hypothesis: CD Vice-Rectorates lack image: the vagueness of the term university extension has made things worse and fads in naming Vice-Rectorates have hindered branding. An overwhelming majority of respondents agreed with the statement (90\%). In our view, the problem lies more in fostering a sub-sector than in purely branding and marketing issues.

15. Hypothesis: The mix of sub-dimensions found in CD Vice-Rectorates gives freedom of action and a strong regional presence. A sizeable majority of respondents agreed with the statement (61\%). This is the positive side of the issue identified in Hypothesis 2 (the bewildering number and variety of subdimensions making up $\mathrm{CD}$ ). Here, the very lack of uniformity and consistency in sub-dimensions confers greater flexibility of action. 
16. Hypothesis: CD activities can be seen as permanent 'Open Days', letting those taking part learn about the university within a context of non-formal learning. This is self-evident but is nevertheless a point worth making. A sizeable majority of respondents agreed with the statement (69\%). That said, universities do not always make good use of this opportunity.

17. Hypothesis: The role of CD Vice-Rectors in fostering interchange between cultural creators and producers on the one hand and university institutes and research groups on the other has been poorly developed. An overwhelming majority of respondents agreed with the statement $(86 \%)$ - something that points to the need to work hard on this aspect of CD programming from the outset, as well as to pool best national and international practices.

18. Hypothesis: The positive image of the institution projected by $\mathrm{CD}$ is one of the strengths of these Vice-Rectorates. The overwhelming majority of respondents agreed with the statement (92\%). Although the point does not only concern CD but also applies to cultural services and products in general, the idea that culture and merit lie behind this positive image is something that has not been widely debated (Musgrave, 1968).

19. Hypothesis: The faculty holding academic posts in these Vice-Rectorates suffer 'burn-out', resulting in them not renewing their terms of office. CD ViceRectorates are a hurdle to one's academic career rather than a springboard. A minority of respondents agreed with the statement (47\%) yet it was highly significant that a sizeable majority of TRS staff agreed with it (62\%). The different views of the two groups (ASS and TRS) stem from Spanish universities' chronic inability to create work teams that overcome the split between administrative and academic staff. The University of Cadiz is a case in point. Despite a 40 (the anniversary fell in 2019), no CD Vice-Rector has served more than a four-year term and none of them subsequently opted for the Rector's post.

20. Hypothesis: The technical staff in these Vice-Rectorates have little job mobility and do not get the recognition they so richly deserve. When they do get promotion, it tends to be in other public administrations, not within the university. A sizeable majority of respondents agreed with the statement (69\%), although the highest percentage of 'don't knows' was highest among TRS respondents.

21. Hypothesis: The university in general and CD Vice-Rectorates in particular exercise little civic leadership. A sizeable majority of respondents agreed with the statement (63\%).

22. Hypothesis: The $\mathrm{CD}$ seeks to be an agent of socio-cultural innovation in the sense meant by Lester in debates on future dilemmas (Lester and Piore, 2006) but currently falls a long way short of achieving this lofty goal. A large majority of respondents agreed with the statement (73\%), revealing the need to do more on this score.

23. Hypothesis: From a training standpoint, the relationship with culture professionals is based heavily on the degree taken, little on post-graduate qualifications, and hardly at all on the university's 'inhouse' qualifications. There was a negligible gap between respondents agreeing with the statement and those disagreeing with it. This was because the percentage of 'don't knows' or who did not answer made up $47 \%$ of those surveyed. It seems there is a great deal of ig- 
norance among those managing $\mathrm{CD}$ when it comes to cultural management of degrees, master's programmes, and universities' own qualifications. This lack of knowledge should make us reflect on the little impact we make as cultural agents on the university itself. For Bonet, when it comes to training in the cultural management field, the challenges facing universities are:

Training teaching teams that: (a) are committed to the professional sector and the communitarian world, thus legitimising their activities; (b) draw upon a trans-disciplinary vision (both intra and extra-varsity) within a cross-cutting approach to culture (...); (c) constitute network nodes and international projects; (d) teach innovatively; (e) are open to rising generations and diverse individuals (to unleash the power of diversity); (f) are part and parcel of the university ethos (Parodi Álvarez 2017: 32-33).

24. Hypothesis: The training orientation of CD Vice-Rectorates (extension courses, summer courses and schools) requires an updating of subjects and teaching approaches. An overwhelming majority agreed with the statement (88\%). This suggests an urgent need to come up with new subjects and take new approaches to the traditional fare found in extension, summer, and seasonal programmes. Furthermore, over many years extension programmes complemented the skills curriculum imparted to university students with over twenty elective credits. This has been whittled down to just six credits over the last few academic years. Here, maybe we could take a leaf out of Latin America's book, where the term extensionista is applied to the rural world and means facilitating learning and pooling of information within the framework of collaboration networks and innovation platforms (Landini, 2016).

\section{CONCLUSIONS}

We draw on all the elements in this expert-validated self-diagnosis to reflect on whether we really have a university cultural policy that is on a par with the teaching, research, and knowledge transfer policies adopted by other European institutions. Following Martinell (Martinell Sempere, 2013), the requirements for a sound cultural policy are:

- A cultural dissemination strategy (democratisation)

- A strategy for fostering and helping cultural creation

- A strategy for building cultural capabilities, based on the two foregoing points

- A communication strategy

In general, given our knowledge of the $\mathrm{CD}$ sector and the study findings, we can say that most Spanish universities meet these four requisites but in many case in a chaotic, poorly-planned fashion. One can therefore say that in Spain, there is only an incipient, limited university culture policy.

Returning to the CD, our main findings on the state of affairs in 2019 are as follows:

1. The CD is not currently identified as one of the university's missions. In the 1990s, university extension was recognised as the third mission (after teaching and research). Nevertheless, our university today sees knowledge transfer as its third mission.

2. The $\mathrm{CD}$ does not appear among the aims in the university's strategic goals and cultural indicators are not included in the rankings, even though such activities are valuable for society.

3. There is no well-established framework for the $\mathrm{CD}$ because its mission remains vague. As things now stand, the CD lies somewhere between university extension and what has 
been called 'university social responsibility'. However, as a multi-dimensional concept, the $\mathrm{CD}$ is properly integrated in these two fields. The host of sub-dimensions embraced by the $\mathrm{CD}$ in both terms content and nature overcomplicate the task of defining it.

4. The CD is deployed in various university spheres (Vice-Rectorate, centres, departments, sections, institutes, groups, and so forth). On the one hand, this can be considered enriching. On the other, it makes it that much harder to draw up strategies and plans.

5. The $\mathrm{CD}$ does not have major infrastructural underpinning within the institution and although it is staffed by professionals, these do not form part of management networks unlike the case of other university dimensions.

6. The CD plays a leading role in some of university life but does not feature on the university's agenda (governance bodies, faculties, social councils). Thus its presence on decision-making bodies is of a token, fringe nature. Paradoxically, despite this $\mathrm{CD}$ is present whether directly or indirectly in almost all university management teams.

7. The CD programmes are remote from students' cultural skills (Morales Sánchez, 2010), which focus on artistic and creative content. In this respect, success bears no relationship to whether the offerings cater to a majority. Likewise, content catering to a minority does not necessarily mean quality.

8. The CD is strongly deployed at the national level but it is not one of the sundry agents playing a leading role in cultural policy (State, Autonomous Communities [regions], local councils, regional boards, cultural industries, creative sectors, cultural associations, and so forth). Creating a formal network of cultural universities would make Spanish institutions more effective in their dealings with their opposite numbers abroad. This is because it would demonstrate a link between over 70 Spanish universities working in the cultural field, and might even help make the country a leader in it.

9. The CD does not form part of a shared agenda in cities, nor does it play the kind of coordinating, integrating role that would be well received by society and cultural agents.

10. The CD has not been able to create its own system of standardised indicators. Instead, people tend to come up with their own evaluation systems (first for comparison purposes, later for improvement ends, and finally to gain recognition).

11. The CD does not cover curriculum and extra-curriculum areas for TRS (Teaching and Research Staff): TRS receive training to improve teaching and research but not on the CD nor how to relate activities in this field with research. Although there are strategies for bringing on those with teaching and/or research talent, universities have so far made little progress in capturing those with cultural talents.

12. Neither the $C D$ nor the university itself exercise leadership or have become key agents when it comes to socio-cultural innovation.

CODA

In our Culture in/from/for/ the University seminar (July 2018), we held a game - half personal, half literary - in which the seminar title created a comprehensive system of relationships between the terms culture and university, depending on the unifying preposition used. We give the list of relationships so generated as a way of posing future challenges in the CD field for Spanish universities: 
From culture to the university. Some cultural institutions have not adapted to the realities of universities.

Culture vis-à-vis the university. Digital culture and/or collaboration is becoming the norm but we remain blind to it.

Culture under the university. This occurs under official structures that we cannot detect.

Culture with the university. This is what many creators and managers seek in our cities and regions.

Culture against the university. This is something we find in other external cultural agents.

The culture of the university. This is a culture that has yet to be defined and built to give meaning to our mission.

Culture from the university. The universal culture that we have inherited from the university extension pioneers.

Culture in the university. Culture that emerges and grows from our campus (promotion).

Culture - between university and society. This is something that we need more of.

Culture shifting towards the university. Cultural management that is still 'emerging' but that has yet to 'arrive'.
Culture to the university. The geographical limits set by our campuses.

Culture for the university. That which we are still unable to properly define and develop.

Culture by the university. Something that most of us here voluntarily shoulder as part of our mission.

Culture according to the university. The official culture that we convey in one way or another from our Vice-Rectorates in the CD field.

Culture without the university. This is what happens in many Spanish cities and at many Spanish university campuses.

Culture on the university. Something that turns us into subjects of cultural research.

Culture after university. Something that we have yet to dovetail with teaching and research.

Culture during university. How we can boost culture among our students during their time at university.

Culture through university. Something that we can generate through research and innovation processes as part of our socio-cultural fabric.

\section{BIBLIOGRAPHIC REFERENCES}

Ariño Villarroya, A. (2007). Cambio de paradigma en la función cultural de la Universidad. In M. Cantos Casenave and A. J. González Rueda (co-ord), Monografía. La extensión universitaria que viene: Estudio prospectivo de escenarios ideales (p.15-44). Cádiz: Servicio de Publicaciones de la Universidad de Cádiz. Source: https://dialnet.unirioja. es/servlet/articulo?codigo=2555891

Ariño Villarroya, A. (2016). 3.1.1 Gestión cultural universitaria. In L. Ben Andrés, V. Rivas Serrano and C. Ojeda Gómez (ed.), Manual Atalaya de apoyo a la gestión cultural. Cádiz: Universidad de Cádiz. Source: http:// atalayagestioncultural.es/capitulo/gestion-cultural-universitaria 
Ariño Villarroya, A. and González Rueda, A. J. (2012). La dimensión cultural de la universidad en el estado español. Periférica Internacional. Revista para el análisis de la cultura y el territorio, 13. Source: https://revistas.uca.es/index. $\mathrm{php} /$ periferica/article/view/1864

Cantero, C. (2006). El concepto de la extensión universitaria a los largo de la historia. Cádiz: Dirección General de Universidades de la Consejería de Innovación, Ciencia y Empresa de la Junta de Andalucía. Source: https:// cercles.diba.cat/cgi-bin/koha/opac-detail.pl?biblionumber $=43548$

Cedeño Ferrín, J. (2012). Tendencias del proceso de gestión de la Extensión Universitaria y su impacto cultural. Rev Humanidades Médicas, 12(3), 499-514. Source: http://www.humanidadesmedicas.sld.cu/index.php/hm/article/ view/247/165http://scieloprueba.sld.cu/scielo.php?script=sci_arttext\&pid=S1727-81202012000300009\&lng=es.

Coronas, S. M. (2005). Altamira: De la cátedra de Historia del Derecho a la Historia de las Instituciones Políticas y Civiles de América. Alicante: Biblioteca Virtual Miguel de Cervantes. Source: http://www.cervantesvirtual.com/obra-visor/ altamira---de-la-ctedra-de-historia-del-derecho-a-la-historia-de-las-instituciones-polticas-y-civiles-de-amrica-0/ html/0046743e-82b2-11df-acc7-002185ce6064_15.html

Draper, W. H. (1923). University Extension: A Survey of Fifty Years (1873-1923). London: The University Press. Source: https:// archive.org/details/universityextens013150mbp/page/n29

Encyclopedia Britannica. (n.d.). University extension. Accessed $6^{\text {th }}$ April 2019 at https://www.britannica.com/topic/ university-extension

Freire, P. (1973). ¿Extensión o comunicación? La concientización en el medio rural. Mexico: Siglo XXI Editores.

García Guatas, M. (2004). Orígenes y circunstancias de la extensión universitaria en España. Alicante: Biblioteca Virtual Miguel de Cervantes. Source: http://www.cervantesvirtual.com/obra/orgenes-y-circunstancias-de-la-extensin-universitariaen-espaa-0/

García, T. (4 ${ }^{\text {th }}$ April 2019). Conferencia de Jaron Rowan en la UCA: ¿Cultivarse o ser cultivado? Diario de Cádiz. Source: https://www.diariodecadiz.es/ocio/conferencia-Jaron-Rowan-UCA_0_1342366337.html

González Rueda, A. J. (2004). 25 años de extensión universitaria en la provincia de Cádiz. In V. Atero Burgos and A. J. González Rueda, Universidad de Cádiz. 25 años (p. 179-206). Cádiz: Servicio de Publicaciones de la Universidad de Cádiz. Source: https://extension.uca.es/wp-content/uploads/2017/10/2708.pdf?u

González Rueda, A. J. (2017). La dimensión cultural de la universidad en el estado español. [Vídeo]. Source: https://www. youtube.com/watch?v=aqJhQR13k2c

Landini, F. (2016). Problemas de la extensión rural en América Latina. Perfiles Latinoamericanos, 24(47), 47-68. DOI: $10.18504 / \mathrm{p} 12447-005-2016$

Lester, R. K. and Piore, M. J. (2006). Innovation: The Hidden Dimension. Harvard: Harvard University Press.

Ley orgánica 11/1983, de 25 de agosto, de reforma universitaria, BOE 209, de 24.034 a 24.042 (1983). Source: https:// www.boe.es/boe/dias/1983/09/01/pdfs/A24034-24042.pdf

Ley orgánica 4/2007, de 12 de abril, por el que se modifica la Ley orgánica 6/2001, de 21 de diciembre, de universidades. BOE 89, de 2.063 a 2.082 (2007). Source: https://www.boe.es/boe/dias/2007/04/13/pdfs/A16241-16260.pdf

Martinell Sempere, A. (2013). 3.4 Modelos de gestión. In L. Ben Andrés, V. Rivas Serrano and C. Ojeda Gómez (ed.), Manual Atalaya de apoyo a la gestión cultural. Cádiz: Universidad de Cádiz. Source: http://atalayagestioncultural.es/ capitulo/modelos-gestion

Mejía Arango, J. L. (2018). La dimensión cultural de la universidad. [Vídeo]. Source: https://www.youtube.com/ watch?v=CLD9JGFVjYQ

Melón Fernández, S. (1987). La extensión universitaria-antecedentes y características. In Clarín y La Regenta en su tiempo: actas del Simposio Internacional. (p. 93-184). Oviedo: Universidad de Oviedo, Servicio de Publicaciones. Source: https:// dialnet.unirioja.es/servlet/articulo?codigo $=903718$

Melón Fernández, Álvarez Antuña, V., Friera Suárez, F. and Ruiz de la Peña, A. (2002). Santiago Melón Fernández. Obra completa. Oviedo: Servicio de Publicaciones de la Universidad de Oviedo. Source: https://publicaciones.uniovi.es/ catalogo/publicaciones/-/asset_publisher/pW5r/content/obra-completa-de-santiago-melon-fernandez;jsessionid=C AC07B6C31604A22AAC2ECEAB2D2C1D0?redirect=\%252Fcatalogo\%252Fpublicaciones\%253Fp_p_id\%253D101_ INSTANCE_pW5r\%2526p_p_lifecycle\%253

Morales Sánchez, M. I. (ed.) (2010). Dossier de trabajo: Competencias culturales de los universitarios. Cádiz: Junta de Andalucía. Source: http://www.observatorioatalaya.es/wp-content/uploads/2018/02/Competencias-Culturales-delos-Universitarios.pdf 
Musgrave, R. A. (1968). The Theory of Public Finance. Madrid: Aguilar.

Palacios Morini, L. (1908). La extensión universitaria. In L. Palacios Morini, Las universidades populares (p. 125-156). Valencia: F. Sempere and Compañía Editores. Source: http://www.filosofia.org/aut/lpm/lup10.htm

Parodi Álvarez, M. J. (2017). Universidad y cultura: balance de una relación. Relato del seminario de verano del Observatorio Cultural del Proyecto Atalaya. Periférica Internacional. Revista para el análisis de la cultura y el territorio, 18. Source: https://revistas.uca.es/index.php/periferica/article/view/4173

Penelas, S. (30 ${ }^{\text {th }}$ April 2013). La dimensión cultural de la Universidad rompe fronteras. El Faro de Vigo. Source: https:// www.farodevigo.es/gran-vigo/2013/04/30/dimension-cultural-universidad-rompe-fronteras/800678.html

Ramoneda, J. (2013). XI tesis sobre la cultura. La Maleta de Portbou. Revista de humanidades y economía, 1. Source: https:// lamaletadeportbou.com/articulos/xi-tesis-sobre-la-cultura/

Red Telescopi. Buena práctica: Observatorio cultural del Proyecto Atalaya. Accessed $6^{\text {th }}$ April 2019 from https://telescopi.upc. edu/detalle-de-buenas-practicas?numero=315

Red Telescopi. Repositorio de Buenas Prácticas. Accessed $6^{\text {th }}$ April 2019 from https://telescopi.upc.edu/buenas-practicas/ buscar-buenas-practicas?page $=$ index $\&$ tipo $=\&$ area $=5 \&$ pais $=8 \&$ filtrar $=$ Filtrar

Ruiz Corbella, M. and Bautista-Cerro Ruiz, M. J. (2016). La responsabilidad social en la universidad española = University's social responsibility at Spanish universities = Responsabilité sociale dans l'université espagnole, 28, 159-188. https:// doi.org/10.14201/teoredu2016281159188

Solicitud de creación de la comisión sectorial de extensión universitaria en el seno de la CRUE (2003). Accessed $6^{\text {th }}$ April 2019 from http://www.cervantesvirtual.com/obra-visor/solicitud-de-creacin-de-la-comisin-sectorial-de-extensinuniversitaria-en-el-seno-de-la-crue-0/html/0046c2e0-82b2-11df-acc7-002185ce6064_2.html

Welch, E. (1973). The Peripatetic University: Cambridge Local Lectures, 1873-1973. Cambridge: Cambridge University Press.

\section{BIOGRAPHICAL NOTE}

\section{Antonio Javier González Rueda}

He was awarded a Degree in History and a University Diploma in Library Sciences and Documentation by Universidad de Granada. González is a university expert in Cultural Management Programmes and was awarded a PhD in Arts and Humanities by Universidad de Cádiz. His is a Cultural Manager at Universidad de Cádiz, and is also an INDESS researcher. González specialises in patrimonialisation phenomena.

\section{Antonio Ariño Villarroya}

Ariño is Full Professor of Sociology at Universitat de València and his research focuses on the Sociology of Culture and Sociology Theory. His most recent publications include Culturas abiertas, Culturas Críticas [Open Cultures, Critical Cultures] (Tirant lo Blanch, 2019) and Cultura Universitaria. Políticas para la Alma Mater [University Culture. Policies for the Alma Mater] (Tirant lo Blanch, 2020).

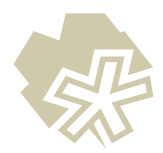




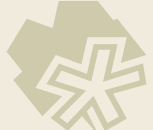

